\title{
A short segment in the HIV-1 gp120 V1/V2 region is a major determinant of neutralization resistance to PG9-like antibodies
}

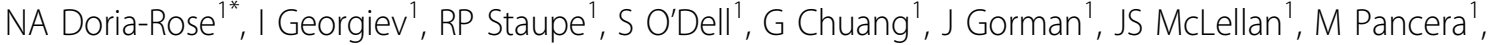 \\ M Bonsignori' ${ }^{2}$, BF Haynes ${ }^{2}$, DR Burton ${ }^{3}$, WC Koff ${ }^{4}$, PD Kwong ${ }^{1}$, JR Mascola ${ }^{1}$
}

From AIDS Vaccine 2012

Boston, MA, USA. 9-12 September 2012

\section{Background}

Antibody PG9 is a prototypical member of a class of V1/V2-directed antibodies that effectively neutralizes diverse strains of HIV-1. The crystal structure of PG9 bound to scaffolded V1/V2 has provided insight into its mode of recognition. We sought to gain a more complete understanding of the interaction of PG9 with the functional viral spike, and to extend our understanding to other antibodies of this class.

\section{Methods}

We analyzed amino acid frequencies in the V2 region of PG9 sensitive and resistant strains to identify potentially important residues. We also used the crystal structure of PG9 with scaffolded V1/V2 to identify potential contact sites. Based on these analyses we designed mutations in PG9 resistant strains with the goal of "knocking in" sensitivity. Parent and mutant Envs were used to make pseudoviruses. The potency of PG9 as well as V1/ V2 antibodies PG16, CH01, CH04, PGT141, and PGT145 against the pseudoviruses was assessed by TZM-bl neutralization assay.

\section{Results}

For $20 / 20$ of resistant strains, mutations in a short segment of V1/V2 resulted in gain of sensitivity to at least one antibody of the PG9 class, and 13/20 showed gain of sensitivity to 3 or more. Mutations in V2 strand C, particularly the addition or substitution of lysine at positions 168,169 , or 171 , had the greatest effects.

${ }^{1}$ National Institutes of Health, Bethesda, MD, USA

Full list of author information is available at the end of the article

\section{Conclusion}

These results highlight the importance of strand $\mathrm{C}$ contacts for neutralization by V1/V2 antibodies, provide functional confirmation of the crystal structure, and suggest a general mechanism of resistance to V1/V2-directed broadly neutralizing antibodies.

\section{Author details}

'National Institutes of Health, Bethesda, MD, USA. ${ }^{2}$ Duke University, Durham, NC, USA. ${ }^{3}$ The Scripps Research Institute, La Jolla, CA, USA. International AIDS Vaccine Initiative, New York, NY, USA.

Published: 13 September 2012

doi:10.1186/1742-4690-9-S2-029

Cite this article as: Doria-Rose et al:: A short segment in the HIV-1 gp120 V1/V2 region is a major determinant of neutralization resistance to PG9-like antibodies. Retrovirology 2012 9(Suppl 2):O29.

Submit your next manuscript to BioMed Central and take full advantage of:

- Convenient online submission

- Thorough peer review

- No space constraints or color figure charges

- Immediate publication on acceptance

- Inclusion in PubMed, CAS, Scopus and Google Scholar

- Research which is freely available for redistribution

Submit your manuscript at www.biomedcentral.com/submit 